\title{
Disparities in Infrastructural Development of Nagaland: A Case Study of Kohima and Longleng District
}

\section{T. Zarenthung Ezung* and Chubakumzuk Jamir}

Department of Economics, Nagaland University, Lumami, 798627

*Corresponding author: tzars@rediffmail.com

\begin{abstract}
A sound infrastructural facility is the key to the overall socio-economic development of a state. Infrastructure facilities are the wheels of development without which the economy cannot function properly. This paper studies the level of physical and social infrastructural disparities in Kohima and Longleng districts using seven indicators such as education, health, banking, postal service, water supply, surface road cover and electricity. The data's were than analyzed using Principal Components Analysis. The results shows that disparities in infrastructure facilities between rural and urban areas is high. The finding shows that 87.5 per cent of the urban areas are developed and moderately developed whereas, only 12.5 per cent of the rural areas are in developed and moderately developed. The paper concludes by suggesting that suitable policies for developing the backward areas.
\end{abstract}

Keywords: Disparities, Infrastructure, Kohima and Longleng

In today's competitive world it is difficult for an economy to seek to be strong without sound infrastructure facilities. Infrastructure development is becoming indispensable in the modernization process of state and urban systems are heavily dependents on infrastructure networks to make their economic and social systems function effectively ${ }^{1}$. The importance of infrastructure for development was recognized early with the emergence of developmental economics. Infrastructure increase economic activity and increases the degree of specialization by lowering production costs, improving quality of life, reducing poverty level, increasing international competitiveness, attracting foreign direct investment ${ }^{5}$, creating access to employment and providing further earning opportunities and raising production of goods and services. The Process of economic development generates regional disparities which is almost a common and global problem. Both developed and underdeveloped countries are griped with the problem of regional disparities and imbalances. Since the different regions grow at very unequal rates, causing inter-regional and intra-regional imbalances, these give birth to various types of socio-economic problems. Many development and growth theories have proved that regional disparities and imbalances are inherent in the progress of development and their degree goes on changing with the stage of economic development. However, there are differences of opinion among the economists about the pattern of regional disparities during the process of economic development, according to Myrdal, the main causes of regional disparities is the strong 'Backwash Effects' and weak 'Spread Effects'. Richer and progressive regions attract net immigration, capital and trade from other parts of the country and this movement by itself tends to favour these regions and disfavour the other regions. Existence of regional disparities in economic development, in vast developing countries like India, is a common phenomenon. Differences in per capita income, agricultural growth, industrial growth, capital etc., are often highlighted to bring out disparities in development of India and different states. Apart from these factors differences in infrastructure development indicates imbalance and inequalities in regional development. Thus, 
present study investigates regional disparities in development of infrastructure in Kohima and Longleng district of Nagaland.

\section{Methodology}

Source of Data and Sample Design: The primary data were collected using stratified random sampling method during 2015-16. The areas were stratified according to geographical division of East, West, North and South zone. Then from each zone, one village and ward were selected for the study. Thus, four villages and four wards from each district were selected. For Kohima district, rural areas of Jakhama, Kijumetouma, Mezoma and Tsiese Bawe and urban areas of Daklane, Lower Chandmari, Sepfuozou and Upper Agri ward were selected. For Longleng district rural areas of Bura Namsang, Nian, Sakshi and Yachem and urban areas of High School, Leinak, Shauli, Shayung were selected for study.

Data Analysis: The collected data were analyzed at the households and individual levels using Principal Components Analysis (PCA). The variables used to measure the disparities in infrastructure development are shown below:

$\mathrm{X}_{1}=$ Education, where the literacy rate of each village and ward taken, $X_{2=}$ Distance from medical facilities, where the inverse of the distance from each village and ward to medical centre is taken, $\mathrm{X}_{3}=$ Distance from banking facilities, where the inverse of the distance from each village and ward to banking centre are taken, $\mathrm{X}_{4}=$ Distance from postal service, where the inverse of the distance from each village and ward to postal centre is taken, $\mathrm{X}_{5}=$ Distance covered by surface road with-in the villages and wards are taken, $X_{6}=$ Distance from water supply, where the inverse of the distance from each village and ward to water supply is taken and $\mathrm{X}_{7}=$ Electricity connection of each household in the village and ward are taken.

\section{RESULTS AND DISCUSSION}

The Principal Component Analysis using 'Factor Analysis' has been used to analyze the inequalities in infrastructure development in Nagaland, Factor analysis seeks to identify a relative small number of factors that can be used to represent relationship among sets of many inter-related variables. Factor analysis assumes that some underlying factors, also known as hypothetical or unobservable factors, are responsible for the co-variation among the observed variable. The factor analysis is based on the assumption that the observed variables are linear combination of some underlying or hypothetical factors. To measure PCA all the variables from $X_{1}$ to $X_{6}$ were used except $X_{7}$ which was left out from assessment because all the sample villages and wards are equally distributed in terms of power. The factor analysis starts with the correlation matrix of the original set of six development variables. Table 1 reveals that there is a negative correlation between $X_{1}$ and $X_{2}$ and positive correlation between $X_{1}$ and $X_{3}$ both statistically significant at 5 per cent. There is also a negative correlation between $X_{2}$ and $X_{3}$ which is statistically significant at 5 per cent.

Table 1: Correlation Matrix of Infrastructure Development of Kohima and Longleng

\begin{tabular}{ccccccc}
\hline Variables & $\mathrm{X}_{1}$ & $\mathrm{X}_{2}$ & $\mathrm{X}_{3}$ & $\mathrm{X}_{4}$ & $\mathrm{X}_{5}$ & $\mathrm{X}_{6}$ \\
\hline $\mathrm{X}_{1}$ & 1 & $-0.768^{* *}$ & $0.628^{* *}$ & -0.200 & 0.286 & 0.116 \\
$\mathrm{X}_{2}$ & $-0.768^{* *}$ & 1 & $-0.523^{* *}$ & 0.292 & -0.095 & -0.013 \\
$\mathrm{X}_{3}$ & $0.628^{* *}$ & $-0.523^{* *}$ & 1 & 0.314 & -0.082 & -0.041 \\
$\mathrm{X}_{4}$ & -0.200 & 0.292 & 0.314 & 1 & -0.296 & 0.265 \\
$\mathrm{X}_{5}$ & 0.286 & -0.095 & -0.082 & -0.296 & 1 & 0.165 \\
$\mathrm{X}_{6}$ & 0.116 & -0.013 & -0.041 & 0.265 & 0.165 & 1 \\
\hline
\end{tabular}

Source: Own calculation; ${ }^{*}$ refers to 5 per cent significant level (except diagonal).

Table 2 presents Factor loading results of infrastructure development in Nagaland for the year 2015-16. The table reveals that three factors have been retained based on Kaiser's Criterion of Eigen-value greater than unity. The first factor explained 38.993 per cent of the total variance while the second factor explained 24.77 per cent and the third factor explained only 19.77 per cent. The three factors taken together explained 83.536 per cent of observed variance. The Factor loadings revealed that the communality value of all the variables varies between 0.715 and 0.901 suggesting that the three factors retained were sufficient to account for most of the variation. The Principal Component Analysis (PCA) of factor 1 loads heavily on education $\left(X_{1}\right)$ and distance from banking facilities $\left(\mathrm{X}_{3}\right)$, whereas the PCA of factor 2 is loaded heavily on distance from postal facilities $\left(X_{4}\right)$. The PCA of factor 3 is loaded heavily on distance from medical facilities $\left(X_{2}\right)$, surface road 
cover $\left(X_{5}\right)$ and distance from water supply $\left(X_{6}\right)$. Thus Factor 1, explain the level of development with regard to education and banking facilities, Factor 2 explained a level of development with regard to postal services and Factor 3 explained the level of development with regard to distance from medical facilities, surface road covered and distance from water supply. Wards and villages having the higher factor scores depict a better performance in terms of infrastructural status, while those with lower factor score show poor performance or low level of infrastructural development.

Table 2: Factor Loading of Infrastructure Development of Kohima and Longleng

\begin{tabular}{ccccc}
\hline Variables & F1 & F2 & F3 & $\begin{array}{c}\text { Communalities } \\
\mathbf{h}^{\mathbf{2}}\end{array}$ \\
\hline X1 & 0.946 & -0.017 & 0.079 & 0.901 \\
X2 & -0.892 & 0.060 & 0.131 & 0.816 \\
X3 & 0.723 & 0.561 & -0.161 & 0.863 \\
X4 & -0.216 & 0.884 & 0.222 & 0.877 \\
X5 & 0.276 & -0.576 & 0.555 & 0.715 \\
X6 & 0.060 & 0.234 & 0.883 & 0.838 \\
\% variance & 38.993 & 24.770 & 19.773 & 83.536 \\
Cumulative \% & 38.993 & 63.763 & 83.536 & \\
\hline
\end{tabular}

Principal Component Analysis I (Factor 1)

Table 3 explains the level of development with regard to factor 1 . It is seen that Lower Chandmari, Daklane, Upper Agri ward (Kohima) and High
School ward (Longleng) are highly developed with regard to education and distance from banking facilities. The moderately developed areas are Sepfuozou (Kohima), Shauli and Leinak (Longleng) and Jakhama (Kohima), while the less developed areas are Shayung ward (Longleng), while Mezoma village (Kohima), Bura Namsang and Yachem (Longleng). The backward areas are Kijumetouma, Tsiese Bawe (Kohima), Sakshi and Nian (Longleng). The PCA of Factor 1 shows that only 12.5 per cent of rural areas and 87.5 per cent of urban areas are developed and moderately developed.

Factor 2 score given in Table 4 shows that the developed areas are High School, Shauli, Nian and Sakshi (Longleng) with regard to distance from postal facilities. The moderately developed areas are Mezoma, Tsiese Bawe (Kohima), Shayung and Leinak (Longleng). The less developed areas are Daklane, Sepfuozou, Jakhama (Kohima) and Yachem (Longleng), Lower Chandmari, Upper Agri (Kohima) Bura Namsang (Longleng) and Kijumetouma (Kohima) fall in the category of backward areas. The PCA of Factor 2 shows that 50 per cent of rural areas and 50 per cent of urban areas are developed and moderately developed.

Table 5 explains the level of development with regard to factor 1. It shows that Jakhama, Mezoma and Upper Agri (Kohima) and Sakshi (Longleng) are the developed with regard to distance from medical facilities, surface road cover and water supply.

Table 3: Factor Score for Infrastructure Development of Kohima and Longleng (Factor 1)

\begin{tabular}{|c|c|c|c|c|c|c|c|}
\hline Developed & Score & Moderately Developed & Score & Less Developed & Score & Backward & Score \\
\hline Lower Chandmari (KW) & 0.888 & Sepfuozou (KW) & 0.634 & Shayung (LW) & 0.230 & Kijumetouma (KV) & -0.763 \\
\hline Daklane $(\mathrm{KW})$ & 0.778 & Shauli (LW) & 0.451 & Mezoma (KV) & -0.275 & Tsiese Bawe (KV) & -0.920 \\
\hline Upper Agri (KW) & 0.716 & Leinak (LW) & 0.429 & Bura Namsang (LV) & -0.277 & Sakshi (LV) & -1.244 \\
\hline High School (LW) & 0.686 & Jakhama (KV) & 0.273 & Yachem (LV) & -0.328 & Nian (LV) & -1.278 \\
\hline
\end{tabular}

KW: Kohima Ward; LW: Longleng Ward; KV: Kohima Village; LV: Longleng Village; Principal Component Analysis II (Factor 2)

Table 4: Factor Score of Infrastructure Development of Kohima and Longleng (Factor 2)

\begin{tabular}{cccccccc}
\hline Developed & Score & Moderately Developed & Score & Less Developed & Score & Backward & Score \\
\hline High School (LW) & 0.997 & Mezoma (KV) & 0.169 & Daklane (KW) & -0.056 & Lower Chandmari (KW) & -0.317 \\
Shauli (LW) & 0.331 & Shayung (LW) & 0.167 & Sepfuozou (KW) & -0.144 & Upper Agri (KW) & -0.341 \\
Nian (LV) & 0.24 & TsieseBawe (KV) & 0.117 & Jakhama (KV) & -0.196 & Bura Namsang (LV) & -0.452 \\
Sakshi (LV) & 0.237 & Leinak (LW) & 0.003 & Yachem (LV) & -0.238 & Kijumetouma (KV) & -0.519 \\
\hline
\end{tabular}

KW: Kohima Ward; LW: Longleng Ward; KV: Kohima Village; LV: Longleng Village; Principal Component Analysis III (Factor 3) 
Table 5: Factor Score of Infrastructure Development of Kohima and Longleng (Factor 3)

\begin{tabular}{cccccccc}
\hline Developed & Score & Moderately Developed & Score & Less Developed & Score & Backward & Score \\
\hline Jakhama (KV) & 0.821 & Yachem (KV) & 0.049 & Lower Chandmari (KW) & -0.115 & Shauli (LW) & -0.197 \\
Mezoma (KV) & 0.218 & Tsiese Bawe (KV) & 0.038 & Kijumetouma (KV) & -0.116 & Leinak (LW) & -0.224 \\
Sakshi (LV) & 0.168 & Shayung (LW) & 0.033 & Daklane (KW) & -0.124 & Bura Namsang (KV) & -0.253 \\
Upper Agri (KW) & 0.13 & High School (LW) & 0.012 & Sepfuozou (KW) & -0.183 & Nian (LV) & -0.255 \\
\hline
\end{tabular}

KW: Kohima Ward; LW: Longleng Ward; KV: Kohima Village; LV: Longleng Village.

Table 6: Combine Component Score of Kohima and Longleng

\begin{tabular}{cccccccc}
\hline Developed & C.C.S & Moderately Developed & C.C.S & Less Developed & C.C.S & Backward & C.C.S \\
\hline High School (LW) & 1.695 & Upper Agri (KW) & 0.505 & Leinak (LW) & 0.209 & Sakshi (LV) & -0.839 \\
Jakhama (KV) & 0.898 & Lower Chandmari (KW) & 0.455 & Mezoma (KV) & 0.113 & Bura Namsang (LV) & -0.983 \\
Daklane (KW) & 0.597 & Shayung (LW) & 0.432 & Yachem (LV) & -0.518 & Nian (LV) & -1.293 \\
Shauli (LW) & 0.586 & Sepfuozou KW) & 0.306 & Tsiese Bawe (LV) & -0.764 & Kijumetouma (KV) & -1.398 \\
\hline
\end{tabular}

KW: Kohima Ward; LW: Longleng Ward; KV: Kohima Village; LV: Longleng Village.

The moderately developed areas are Shayung, High School (Longleng), Yachem (Longleng) and Tsiese Bawe (Kohima). The less developed areas were Daklane, Sepfuozou, Lower Chandmari and Kijumetouma village (Kohima). Sahauli, Leinak, Bura Namsang and Nian (Longleng) fall in the category of backward areas. The PCA of Factor 3 shows that 62.5 per cent of rural areas and 37.5 per cent of urban areas are developed and moderately developed.

\section{Combine Component Score (CCS)}

The Combine Component Scores is calculated by taking the value of factor 1, 2 and 3 along with the variance of each factors and is depicted in table no. 6 . The combine component score shows the overall development index of the districts and they are categorized as developed, moderately developed, less developed and backward areas. The Combine Component Score from the seven indicators shows that the most developed areas are High School (longleng), Jakhama, Daklane (Kohima), and Shauli (Longleng). The moderately developed areas are Upper Agri, Lower Chandmari, Sepfuozou (Kohima) and Shayung (Longleng). The less developed areas was Leinak and Yachem (Longleng), Mezoma and Tsiese Bawe (Kohima). Sakshi, Bura Namsang, Nian (Longleng) and Kijumetouma (Kohima) came in the category of backward areas. This shows that 87.5 per cent of the urban areas and 12.5 per cent of the rural areas are developed and moderately developed. Thus, we can infer that urban areas are more developed than the rural areas.

\section{CONCLUSION}

From the discussion it is seen that only 12.5 per cent of rural areas of Nagaland are in developed and moderately developed, while 87.5 per cent of urban areas are in developed and moderately developed in terms of education and banking. It was also seen that 50 per cent of rural and urban areas are developed and moderately developed in terms of postal services. Moreover, it was also found that 62.5 per cent of rural areas and 37.5 per cent of urban areas are in developed with regard to road, medical facilities and water supply. From the overall development it is found that 87.5 per cent of the urban areas and 12.5 percent of the rural areas are in developed and moderately developed. Thus, we can infer that urban areas are more developed than the rural areas. Therefore, it is suggested that necessary steps be taken to give better education and banking facilities to the rural areas. Moreover, with regard to postal facilities, it is suggested that more branches be opened in both the rural and urban centres for better communication. With regard to road, medical and portable water supply, it is suggested that more priorities be given to the rural areas. For overall development and to make the state an egalitarian society, it is suggested that government give importance to these basic infrastructure development in the rural areas. 


\section{REFERENCES AND NOTES}

Marvin, S. and Graham S. 1994. "Telematics and the Convergence of Urban Infrastructure: Implications for Contemporary Cities," The Town Planning Review, 65(3): 227-242.

Myrdal, G. 1968. Asian Drama-An Inquiry into the Poverty of Nation, Harmondsworth, Penguin Publisher House, London.

Bougheas, S., Demetriades, P. and Morgenoth, E. 1999. "Infrastructure, Transport costs and Trade," Journal of International Economics, 47(1): 169-189.

Romer, M Paul. 1987. “Growth Based on Increasing Returns Due to Specialization" The American Economic Review, 77(2): 56-62.
Henderson, J., Dicken, P., Hess, M., Coe, N. and Yeung Henry, W.C. 2002. "Global production networks and the analysis of economic development," Review of International Political Economy, 9(3): 436-464.

Ghosh, B. and De, P. 1998. Role of Infrastructure in Regional Development: A Study over the Plan Period', Economic and Political Weekly, 33(47/48): 3039-48.

Myrdal, G. 1957. "Economic theory and under-developed regions" G. Duckworth, London.

Hotelling, H. 1933. "Analysis of Complex Statistical Variable into Principal Component", Journal of Education Psychology, 24. 
